Etnográfica

Revista do Centro em Rede de Investigação em

Antropologia

vol. $19(2) \mid 2015$

Vol. $19(2)$

\title{
The Pentecostal reworking of male identities in Brussels: producing moral masculinities
}

Reconfigurações pentecostais de identidades masculinas em Bruxelas: a produção de masculinidades morais

\section{Maïté Maskens}

\section{(2) OpenEdition}

Journals

Electronic version

URL: https://journals.openedition.org/etnografica/4020

DOI: $10.4000 /$ etnografica. 4020

ISSN: 2182-2891

\section{Publisher}

Centro em Rede de Investigação em Antropologia

\section{Printed version}

Date of publication: 1 June 2015

Number of pages: 323-345

ISSN: 0873-6561

Electronic reference

Maïté Maskens, "The Pentecostal reworking of male identities in Brussels: producing moral masculinities", Etnográfica [Online], vol. 19 (2) | 2015, Online since 22 June 2015, connection on 10 February 2022. URL: http://journals.openedition.org/etnografica/4020 ; DOI: https://doi.org/10.4000/ etnografica. 4020

\section{(c) (i) (8)}

Etnográfica is licensed under a Creative Commons Attribution-NonCommercial 4.0 International License. 


\section{The Pentecostal reworking of male identities in Brussels: producing moral masculinities}

\section{Maïté Maskens}

Addressing the paradoxes of gender in Pentecostal churches attended by converts of African or Latin-American origin in Brussels, it is argued that religious and migratory experiences are intimately intermingled in these spaces and that, in most cases, the geographical shift experienced by male believers has led to questions regarding their "traditional" masculinity. Their capacity to hold the role of breadwinner has often been undermined and they experience a kind of vulnerability against which religious gendered ideology often provides assurance and self-esteem by affirming men as heads of the religious space and chiefs of the household unit. Pentecostal masculinity, although adhering to a model of hegemonic patriarchal masculinity regarding the sexual division of domestic tasks, the recognition of men's formal authority, and an exclusive focus on young women as the purity "capital" of churches, also reveals significant ruptures with that model: religious discourse values domestic involvement, sensibility and gentleness, encouraged and valorised as masculine characteristics. This hybrid posture of Pentecostal masculinity appears as a contrasted gender repertoire allowing men of the church to oscillate between various identifications and social locations according to specific situations and different contexts of enunciation.

KEYWORDS: masculinity, Pentecostal churches, migration, agency, gender, hegemonic masculinity.

Reconfigurações pentecostais de identidades masculinas em Bruxelas: a produção de masculinidades morais - O artigo trata os paradoxos de género nas igrejas pentecostais com fiéis africanos e latino-americanos em Bruxelas, argumentando que as experiências migratória e religiosa estão intimamente ligadas nestes espaços e que, na maioria dos casos, a mudança geográfica vivida pelos homens crentes conduziu a que questionassem a sua masculinidade "tradicional". Estes homens veem muitas vezes ameaçada a sua capacidade para assegurar o sustento da família e experimentam por isso alguma vulnerabilidade, que a ideologia de género da sua religião contraria dando-lhes maior segurança e autoestima, ao afirmá-los como dirigentes do espaço religioso e chefes de família. Se bem que a masculinidade pentecostal adira a um modelo de masculinidade patriarcal hegemónica no que respeita à divisão sexual das tarefas domésticas, ao reconhecimento da autoridade formal dos homens e à visão das jovens mulheres como detendo a exclusividade do capital de "pureza" destas igrejas, ela revela também ruturas significativas relativamente a esse modelo: o discurso religioso valoriza o envolvimento doméstico, a sensibilidade e a brandura, encorajados como características masculinas. A masculinidade pentecostal torna-se assim um repertório de género variado, permitindo aos homens a oscilação entre várias identificações e posicionamentos 


\begin{abstract}
sociais em função das situações específicas e dos diferentes contextos de enunciação.
\end{abstract}

PALAVRAS-CHAVE: masculinidade, igrejas pentecostais, migração, agência, género, masculinidade hegemónica.

MASKENS, Maïté (mmaskens@ulb.ac.be) - Université Libre de Bruxelles, Belgium.

\title{
INTRODUCTION
}

Over the past 30 years, Pentecostal churches, mostly composed by followers from Subsaharan Africa and Latin America, have blossomed in Brussels. ${ }^{1}$ Their presence and growing success have gone hand in hand with the intensification of the migratory flows, in the last three decades, from these two continents. In my work, I investigate the relationship between the religious experience and the migratory route of the Euro-African and Euro-Latin-American Pentecostal actors in Brussels (Maskens 2012, 2013). My fieldwork consisted of spending time with followers of mainly (but not exclusively) two different Pentecostals churches in Brussels. The first, La Parole Vivante, is a foothold in a big US transnational Pentecostal denomination (the Church of God, of Cleveland) and gathers around 3000 followers in Brussels. The majority are Congolese but there is also a wide range of other Africans, Latin-Americans and European nationalities (cults are mostly given in French); the second is the Centro Jesús, a local church of the Assemblies of God which gathers around 60 believers from different countries of South and Central America and is located near the South Station in Brussels; their cults are given in Spanish.

In these meeting spaces, the converts work collectively to realize the transformation process encouraged by this religious scenario, which consists of applying the "perfect plan of God" to their lives. Carriers of missionary ambitions, the believers give new contents to their position by redefining the place that is assigned to them in the context of post-colonial Belgium. The religious membership operates as a marker of distinction, a process particularly striking in the field of gender and sexuality within the assemblies.

Conversion to Pentecostalism may also lead to gender conversions. Gender is understood here according to the definition of the American historian Joan Wallach Scott (1988: 42), as "a constitutive element of social relationships

I I would like to warmly thank Ruy Blanes, Annelin Eriksen and Rijk Van Dijk for their insightful and generous comments on a previous presentation of this text in Bergen, Norway, in March 2014. I thank also Kate Nialla Fayers-Kerr for her support. 
based on perceived differences between sexes." The historian adds that "gender is a primary way of signifying relationships of power," as the specific ground of Pentecostals masculinities will testify. Ideologies and religious practices contribute to, define, and more specifically produce particular sexual identities.

During my immersion in these religious settings, my attention was first drawn to women's experiences and their social status in churches. The large female presence at these congregations - even if women's submission to men, as called for by Saint Paul, continues today - could be surprising. This has led me to ask what advantages Pentecostal affiliation brings to the women of the assembly given the apparently oppressive and patriarchal character of this religious ideology. Moreover, this "emotional" Protestantism is often associated with a feminine religiosity, characterized by concepts still thought of in the contemporary western secular world as typically feminine: spontaneity and the expression of one's emotions.

This interest in the condition of women in churches falls within the scope of the rupture with the "triple marginalities" these women generally suffer as described by Nancy Eiesland (1997). First, women are commonly excluded from leadership in religious spaces. Moreover, until recently in the scientific field, women have often been absent from analyses which consider men's experience as illustrative of the whole religious experience. Finally, these pious women are excluded from feminist studies. Indeed, feminists suggest that they are "mystified" by themselves, in other words, they have a "false consciousness" (Eiesland 1997: 100). Absent or marginalized, viewed as vulnerable or eternal victims of men, women have been "saved" in socio-anthropological research by the concept of agency, a notion born in the wake of feminist and gender studies to theorize the way women resist, subvert, negotiate or still inhabit the patriarchal gender norms (Butler 1993; McNay 2000; Hollywood 2004; Mahmood 2005; Bracke 2008). As Adriaan Van Klinken (201 1: 123) put it, men, as gendered beings, were excluded of the analytical benefits of the concept of agency because of the trajectory at first "feminist" of the term.

When examining the abundant literature on gender and religion (Campiche 1996; Voyé 1996; Eiesland 1997; Lawless 2003; Mate 2002; Hallum 2003; Fancello 2005; Sackey 2006), I realize that, in the studies focusing on religious women's experiences, men appear not so much as dynamic subjects but as a given, an unchanged and independent variable always holding the same role in different gender scenarios, in particular that of the oppressor. It is precisely this fixed, reductive aspect of this description of religious masculinities that fostered me to investigate this field. I concur here with Adriaan Van Klinken (2011) on the fact that male power is simply assumed and contested rather than explored. This attention to religious men's agency also matches with Björn Krondorfer's (2009) work, where he investigates “critical men's studies 
in religion" and states the existing risk of reverting to a "long tradition" of repetition of male dominance in the field of religion.

My own interaction with male followers through what is commonly called "fieldwork" also prompts me to question forms of masculinity in these religious spaces. As time passes, I realize followers engage with me according to their own gender conception. Ethnographic relations are hybrid, an experience that doesn't fit very well with the form of interaction in these religious spaces, especially as a female meeting with male individuals. Some men clearly shun my company, apparently uneasy by my inquisitive or even adventurous behaviour. Indeed, I didn't have any male referents (a father, brother or husband) during my visits at these religious gatherings. I share this very same situation with other female followers but, unlike them, my scientific approach forces me to adopt a proactive posture. My conduct deviates radically from the way women are supposed to behave in this religious setting: as a discrete, modest and devoted agent, although some degree of feminine exuberance is tolerated if the woman has a high charismatic capital.

Barbara Rose Lange, American anthropologist and violinist, lived through a similar experience when she tried to integrate into a group of gypsy musicians in a Hungarian Pentecostal church in the 1990s. Within the framework of the musical performance of the cult, her attempts at participation were ignored. The musicians even expressed their tension through specific physical movements. These marks of resistance inform the anthropologist that her presence as a woman in the group of male musicians was not welcome. Indeed, in a general way, the public exchanges between men and women (married or not members of the same family) in these cults are seen in a suspicious light, entering rather quickly into the category of "fornication" (Lange 1996: 68). In a broad sense, religious believers see themselves as the last bastion of morality in a Europe viewed as "decadent." The domain of sexual practices is then the object of profound criticism. Setting the scene as such, faithful Pentecostals construct their differences in the register of sexuality. Attempting to make order out of transformation and pursuing an ideal of distinction, these religious actors (mainly women) need therefore to be unlike the locals, whom pastors have denounced for their permissiveness and "lax" sexual practices (partially legal prostitution, lack of public "decency," legality of same-sex marriage, pornography accessible to young people, STD prevention campaigns in the schools...) (Maskens 2011 ).

This paper is guided by the desire to answer two questions. The first one is articulated around the specificity of male experience in the church: what is the definition these men give to their masculinity? What I mean here is masculinity as a range of "norms, values and behavioural patterns expressing explicit and implicit expectations of how men should act and represent themselves to others" (Miescher and Lindsay 2003: 4). The second question deals with the 
normative religious injunction to "live in the difference," and how this translates at the level of masculine identities; in other words, I want to understand why these men perceive themselves as different from those they deem to be non-religious men.

\section{FROM “OLD MAN" TO “NEW MAN" NARRATIVES}

Conversion in Pentecostal Churches is a central and structural theme of religious thought and concrete organization. As such, the concepts of transformation, change and rupture are crucial in understanding the Pentecostal work on gender identities. Indeed, conversion is thought as a moment of rupture between a past life and a "new" life. Specific narrative tools are used in order to ritualize this religious change. To publicly and regularly testify to this change is at the heart of the religious missionary apparatus and constitutes a keystone in the worldwide diffusion of the movement. Religious models guide the performance of sexual identities. For the men, this transformation implies a behavioural change. ${ }^{2}$

For Jean-Jacques, a Congolese pastor responsible for a small assembly of about 50 people situated in a precarious neighbourhood of Brussels (Molenbeek), this imperative for transformation requires a phase of "breaking." He warns his believers during the cult: "The seed that God puts in you does not avoid that your personality remains!"

His expression is testimony to the effort of self-development that new male converts must do; far from the presumed spontaneity of the transformations assumed in most conversion narratives. It is thus necessary to fight, by means of prayers, to tame the male chauvinist or rebel character of some believers ("philanderers"/"womanizers," "fighters," "disobedient"). The discourse of Jean-Jacques calls for certain adjustments of the personality of male converts. He explains how to sort out diverse features of the Christian personality:

"Because when the Bible says 'it is necessary to crush the flesh,' the first thing which it is necessary to crush, is the character that you have. If you are a philanderer, a womanizer, it is necessary to break it because that is a part of your emotional features. If you are a disobedient person, who does not yet accept the obedience due to your own parents, there is a problem. Because to serve the Lord does not exclude this propensity of the character to rebel. Thus, often, we say that a good pastor has to pass by the stage of breaking; that means he has to break with all the education he received which is

2 The religious speech has no monopoly of the imperative of men's transformation - we think here of the feminist movements, the speech of certain NGO or still some masculinist movements, for example. 
opposite to the ethics and the morality. Because there are always people who support the idea that it is good to hurt somebody. In our Congolese societies for example, we tell you: 'fetch this child and hit him hard' and it is normal, that doesn't shock anybody. But to serve the Lord, if you are a fighter for example, or emotionally disturbed, or if at every slightest problem you are going to dash into the fight, it is necessary to avoid all these behaviours by the prayer, we will break that." [Jean-Jacques, pastor in Molenbeek.]

This quote illustrates the ideal figure of Christian men: male converts must swap their seductive ambitions for the cultivation of peace and dialogue. The male believers are encouraged to "fight" against what is sometimes presented as their deeper "nature," or in other words, to work on their behaviour and actions so that these start resonating with the peaceful figure of Christ. In this religious context, the "strong man" is quiet, moderate, and obedient; he never gets angry, masters his physical strength and shows a constant loyalty to his wife. The "stage of breaking," this "crushing of the flesh" involves the repression of certain features of the "hegemonic masculinity" that are contrary to the Christian ethos.

In another assembly, the Spanish-speaking Centro Jesús, a couple from Ecuador who were carrying out missionary work in Europe were received by pastor Diego in the autumn of 2007 in Brussels to testify, in front of the Assembly, God's action in their lives:

"Wednesday, 7:12 pm. The Peruvian pastor thanks the members of the assembly for being there and numerous this evening for the 'special worship for families.' Without transition, he intones a song entitled To Jump as Kids, accompanied by an electric guitar and drums. In every chorus, the believers jump up as if they were children to express, according to the words of the song, 'the enjoyment of the Lord.' Pastor Diego then asks us to welcome a couple of 'children of God,' Hugo and Alfonsina, who have specially come to give their testimony for us this evening in Brussels. He asks the Lord to bless them and to bless the 'words that will come from their mouths.' The Ecuadorian couple rise then to the altar. Their four daughters sit in the front row; the youngest gives the full room a sweeping glance and she seems satisfied. Pastor Hugo speaks by presenting his wife: 'I present you my wife, Alfonsina, she is the woman who stole my heart.' He hands us over to her, and she pursues this by preaching in two voices, asking the assembly 'to fasten their seatbelts,' to get ready to receive words 'which are nothing but God's words.' She continues by warning the assembly: 'Good intentions alone are not God's will.' That is why, according to her, it is urgent 'to cut family ties because dependence on your family prevents you from being a member of God's family.' The woman pastor then illustrates her comment with the 
lives of a series of biblical characters and gives a kind of tree points recipe to insure a successful and 'harmonious' family life. Then, Pastor Hugo adds a fourth point to those expressed by his wife; it is, he says, 'about something which has already stolen many blessings from families! It is [about] the lack of forgiveness. When we do not forgive, on both sides [he mimes a pyramid of conflicts growing with his hands], it is the higher sin, I am going to give you a technique, a thermometer, to know if we forgave the other one: if things that previously made us angry, we do not speak about them anymore, then we know that forgiveness is in the home.' He addresses then the assembly and asks: 'Who has never had problems in his marriage? The one who gets up, pray for him, for he is a liar!' [The believers laugh]. He continues: 'The victory is in the management of the conflicts.' He turns to elements in his personal life: 'Before, my life was a life of vice, of lust. I drank a lot, I liked parties, I went out. In the village, I had several girlfriends and my wife knew it, but she did not want to see, so she closed her eyes. [His wife, who is held next to him, agrees sadly]. Then we accepted Jesus and in two nights, all our defects were erased. At first, the first night, I apologized to her, several times. I approached her to speak to her, but my wife was irritated, because she did not want to speak to me anymore. She rejected me. I, for my part, was resigned to losing the woman of my life. I wanted to become better. When you look for God, he changes even the tone of your voice. Then, the next day, my wife came to apologize to me. She had a dream and she had seen Jesus writing my name in a book, like that, in the hand, he wrote 'Hugo' in his book. Then she knew and she forgave me.' The South American pastor moves on to the necessity of changing our homes, since 'we live [during] the ultimate time, the evil increases in the world... If we look around, we see how the enemy is inclined to destroy our families. Eight out of ten classmates of our daughters have divorced parents. Figures are alarming and people find it normal. But we are not going to let go, by means of God, we can achieve everything!' He concludes his preaching by recalling the main qualities of the Christian husband: loving, affectionate, attentive, generous and responsible. He reminds those wives who walk in 'the steps of Jesus.' Then he asks the couples present in the room to come to the front of the assembly. The couples get up and stand in front of the stage. He asks them to hold hands and to embrace. The pastor encourages them: 'Go, you can make it. Don't be afraid of being ridiculous, we never miss a little romanticism in this world!' And he asks the husbands to pronounce a sentence to their wives: 'My love, I apologize to you.' Then he suggests changing the roles and it is women's turn to apologize to their husbands. The believers are looking straight in each other's eyes. Some cry openly, others are very discreet. The children, the teenagers and the single members of the assembly contemplate this spectacle from the audience." [Author's fieldnotes.] 
In this rhetorical account, the conversion is presented as a radical rupture with an "old" macho way of life with its specific virile behaviours, geographies and temporalities. Hugo multiplies "guilty" experiences in the village, his wife knowing about his infidelities. The encounter with God changes his masculinity. God changes him even to the "tone" of his voice. The new Hugo realizes that he is losing the "woman of his life" and in his narrative, he becomes faithful, loyal, attentive and affectionate. He encourages believers to connect with their "romantic partner." From a mujeriego, ${ }^{3}$ Hugo becomes an affectionate husband. Seduction has no more "power" over his life. His preoccupations have been refocused into the domestic sphere. His life is no longer outside but inside the home, close to his family.

The figure of the "macho man," because of the Mexican origin of the term, has a particular relevance in the Latin-American religious context. ${ }^{4}$ In the Churches composed by followers from African sub-Saharan countries, this figure is not so prominent. What seems obvious, in these transnational universes which bring together people from different backgrounds, is that there is a plurality of masculinity models coexisting in these assemblies. Indeed, these religious spaces are dense with people from diverse ethno-national origins implying great diversity. If we were to focus only on the story of African masculinity, which has been called by some commentators a "patchwork of patriarchies" (Bozzoli 1983), we would have to analyze in detail the masculinity models integrated by each follower according to their socialization in a particular African socio-historical context. We would also have to look at the colonial situation in which the West, by imposing its masculinity norms, has caused disruptions in the varieties of gender regimes in current use. ${ }^{5}$ As a matter of fact, it would also be useful to sort out the continuities, to describe the contradictions, to search for concordances, conflicts or resonance of these different norms.

Masculinity studies show that there is not one model of masculinity, but a lot of masculinities, a multiplicity of forms of "being a man" in a society and at a given historical moment. This masculinity is multiple, historic and contingent but also relational and contradictory (Hodgson 2001). The male actors are thus confronted with several competitive or contradictory alternatives and

3 Mujeriego is a pejorative Spanish terms that means "womaniser."

4 The term "macho man" emerges during the Mexican revolution of 1910 and will know its peak thanks to the cinema and to the nationalist literature of the 1930s. Afterwards, this term will take negative connotations which will concentrate in the figure of the "male chauvinist" (Machillot $2011)$.

5 Numerous historians underlined the gender dimension of colonialism and of imperialism more broadly. They observe how masculinities of the colonized were weakened by its loser's status. This loss of power moves the colonized man closer to the world of the women according to the definitions imposed by the colonizer (see Mackenzie 1989; Sinha 1995; Joly 2011). 
their way of being a man is constituted by their commitment to, their resistance against, or their subversion of the various male models proposed by their social worlds. It is in this space of negotiated gender standards that Adriaan Van Klinken (201 l) sees the possibility of reading male agency. These various models don't have the same weight in a social setting, since they are not valued in the same way, and this is what permits the distinction of a dominant model, which Bob Connell called the "hegemonic masculinity." This is the form of masculinity which prescribes the image of the "real man" in a given society. This hegemonic form stands out as a model throughout the daily socialization of boys and girls, and other forms of masculinities are subordinated, collusive or marginal to it. The dominant model does not exclude the existence of alternatives but it distinguishes itself because it enjoys a wide social adhesion. The author takes then the hegemonic north-American masculinity as an example: "Few men are Bogarts or Stallones, many collaborate in sustaining those images" (Connell 2002: 61).

This complex heterogeneity constitutes the major reason for largely focusing on male contemporary religious experience, given such a diachronic view of the phenomenon: the process of religious homogenization of masculinities and the implications of these "transformations" on the process of "being men" in the assembly. What then does the Pentecostal reworking of masculinities consist of? What are the possibilities of redefining the ways of being a man in the assembly? How do men understand and appropriate these new gender norms? We will see that it is again ambiguity that is at the heart of Pentecostal transformations of gender identities.

On the one hand, the religious discourse on masculinity comes to strengthen, to support, to consolidate, to biblically legitimize male domination, the ascendancy of men over women, patriarchy, the primary power of the men in and outside the assembly. I resume those processes by the emic expression of "strong men," this strengthening taking quite a particular acceptance in the migratory context as we will see in what follows. On the other hand, the Pentecostal work on masculinities also breaks with the dominant cultural model of masculinity, the local "hegemonic" masculinity. The Pentecostal man distinguishes himself from the "ordinary" man because he is projecting himself as sensitive, communicative and responsible, an exemplary father, whose concerns are concentrated on the well-being of his family. Collectively such attributes are for "men of heart."

After all, the Pentecostal work of masculinity such as it is practiced in Brussels (but also in other European capitals and in other continents) is characterized by the polarized and paradoxical power to challenge and to adapt itself at the same time - to be both "strong men" and "men of heart" -, to produce breaks in continuity (Willaime 1999). 


\section{RELIGIOUS “STRONG MEN”}

Christendom, as a view of the world, contributes generally to the definition of a gendered morality. This sexual ideology draws upon, in the discourses of the Pentecostal pastors, frequently quoted biblical references. One of them, concerning the legitimate form of the relations between men and women, is Saint Paul's famous order which encourages Christian women to be subjected to their husbands (Ephesians, 5: 22-24). Such references justify ways in which inequality between the sexes structures gender interaction, and this encouragement is representative of a kind of patriarchal heteronormativity which is present in religious writing (Delaney 1998). This one patriarchal norm is put into practice during religious activities through a preferential association between the men of the assembly and positions of power. The idea of "gender justice" is absent here in the religious ideology of male transformation. As Cucchiari (1990: 691) showed, the Pentecostal experience follows differentiated outlines: the women are more inclined to live religious experiences in connection with the Holy Spirit, while the religious experience of the men of the assembly is more associated with the words, writings and the formal power of definition.

However, contrary to the Catholic model which automatically excludes women from Ministry (Voyé 1996), the Protestant churches eventually admitted women pastors during the second half of the $20^{\text {th }}$ century for the Reformed and Lutheran Churches (Willaime 1996: 30). This evolution has been the result of a series of social-cultural changes to which Protestantism was not insensitive. In the Pentecostal worlds, it thus happens that women speak and step upon the altar or become pastors even if these events are rare. Whatever their status, their voice is more conditioned than that of the men. When women take the floor, their discourse is full of oral cautions and they have to refer to God ceaselessly to guarantee their legitimacy. This entity appears as an indispensable part of women's religious agency (Hollywood 2004). When women rise to the altar, it is sometimes to remind their sisters of the imperative of intrinsic submission in gender relations, as did "Maman" Jessica, a Congolese representative of the group of the women, in a presentation where she performed a public act of submission during a convention, April 15th, 2006:

"I want to speak to my sisters. The church begins at home, there is no use to come to the church if we leave the house in a mess. To me, my husband is my witness, before coming to church, I take care of the house, cook, I must be subjected to Dad, Roger, [everybody applauds and shows approval by chanting 'Alleluias!' 'Amen!'] I must be subjected to my mother-in-law. God said, 'If you want that I use you, you have to be subjected.' I regret, my sisters. I preach God's word. My sisters, juvenile delinquency begins at home. 
In this country, we have to respect husbands. Applaud the brothers! You the dads, pastors, you are leaders. Take your responsibilities! [The assembly applauds] God does not need omelettes." ${ }^{6}$

In this extract, "Maman" Jessica recalls the major principle valorising certain forms of gender relations in these religious spaces. She recalls the imperatives of submission and the domestic role of women (the house as their kingdom) and, correlatively, the role of men as heads of family. This message, carried by "Maman" Jessica's feminine voice, is one of male precedence. It is the domination of women by men that is highlighted here in spite of the "regrets" expressed.

\section{WEAKENED MIGRANT MEN}

In the migratory context that has seen the emergence of these churches, the discourse of strengthening the male power, illustrated through its biblical roots, takes particular meaning.

First, for the vast majority of the followers, masculinity seems to have been shattered during diverse migratory experiences. As Abdelmayek Sayad (1999) has shown for the case of three generations of Algerian men migrating to France, the social cost of migration is considerable. In his exploration of the dimensions of suffering brought about by migration, the uneasiness takes on various forms and intensities: from culpability generated by a sentiment of abandon to the problem of absence or oblivion, in the country of origin, towards different pathologies of exile (melancholia, excessive pessimism or mutism). For the French-Algerian sociologist, the capacity of the migrant to counter this social cost of migration resides in his ability to give a deep meaning to his existence marked by mobility. In this context, a strong religious affiliation can provide migrants with a particular perspective on the meaning of their lives as this contribution exemplifies. Pentecostal affiliation seems to temper the difficulties faced by migrant men. At the beginning, the resettlement of migrant men often constitutes a self-reflexive starting point - by effect of contrast - on the appropriate forms of gender relations. In this Western European country where these men try to settle, gender standards are different and sometimes contrast with the norms they have incorporated during their former periods of socialization, the form that appears "normal" to them. Often, taken aback by the type of relationship between men and women in

6 In this French-speaking context, the use of omelette takes a particular significance. French speakers use the suffix -ette to form nouns with an idea of smallness (example: camion is a truck and camionette is a small truck). In the preaching of "Maman" Jessica, the use of the expression omelette is a pun to refer to "reduced" men. 
this new context, male followers refer to the religious message to criticize this specific configuration. Similarly, other researches, such that of Sharon Suh (2003), show how Korean Buddhists in America use religion to understand the relationship to the homeland which happens, in part, in gendered ways. Men assert an identity through religious activities that construct distinctively male spaces in the temple, in response to the degrading aspects of the male immigrant experience (Suh 2003).

The discourse of many current believers in Brussels is close to a reaction against various "modern" changes in the sexual field, as a result of several years of the feminist struggle that has contributed to "erode masculine authority in the household" (Illouz 2012: 125). In a certain sense, Pentecostal churches in Brussels are keeping with a broader movement of protest against a universal tendency of women participating in the "globalized" world and market economy (Brouwer, Gifford and Rose 1996: 219).

Therefore, in this context, a lot of male followers take up arms against gender relations as they are represented in Belgium. The issue of equality and leadership are questioned. According to Félix, a follower of about 30 years from the DRC, women's role in Belgian society is not appropriate: "When I get together with white people here, there is some stuff I cannot tolerate, or I cannot accept. When [in quotation marks] 'women take up authority over men and decide everything,' I find it hard. I can't help thinking something is wrong!"

The migratory situation and the resulting new economic order influences gender to a great extent. The loss of economic status changes gender interaction. Various scholars have underlined the challenge to men's authority in migratory contexts (Hirsch 2007; Kibria 1993; Pessar 1995). In Belgium, this loss of masculine privilege is expressed also through the denunciation by men of the "favouring" of women in the local economy. Men say they suffer from this preferential treatment given to women in which their own professional opportunities are fewer. Speaking about job opportunities in Belgium, Martin, a young Congolese-Belgian explains that, "women find work more easily here because Belgium favours women." According to him, this situation is "unbalanced" because women are the only breadwinners and this seems to germinate future conflicts. Indeed, the differential status these men mostly suffer from in a migratory context deprives them, in some cases, from part of the functions and responsibilities they used to have, such as providing food, or more generally taking financial care of the family. In such cases, economic dependence of these men upon their spouses brings their power into question. Some men confess they feel that their identity is at stake, that they are no longer able to control their wives as they did in their native country. This is maybe why a great emphasis is put on the spiritual responsibility of men in the family. 
The contestation of power in gender relations and the tensions which ensue from it in the migratory context resonate with other debates and challenges to patriarchy that are taking place in Africa. Here also, numerous women assume an economic role within the family unit. Indeed, in the case of the Democratic Republic of the Congo, the role of breadwinner associated with the Congolese masculinities (Jewsiewicki 2004; Kuyu Mwissa 2008) is more and more assumed by the women because of the delicate and generalized socioeconomic condition. In her study of the God of Maman Olangi in Congo-Kinshasa and in the Congolese diaspora, Bénédicte Meiers (2013) shows how transformations and economic crises made women's money a necessity to household survival, a change men found hard to accept and thus at the root of a lot of gender tensions. The association between the breadwinner and male skill becomes the object of a competition between men, women and children. In light of this, Meiers explains how the religious ideology of the Church of Maman Olangi contributes - as in the case of Pentecostal churches - to the recovery of male authority.

In Belgium, when men of the assembly do not complain of being victims of discrimination in the hiring process, and when they have access to the realm of work, they regret very often that their occupation is below their skill set. These work experiences are lived as degrading ones (which is very often also the case for their wives). This disqualification in the professional world is not without consequences for the way they think about themselves as men. The migratory context is a continuation of colonial history (Bancel et al. 2010), since the racism of that time contributed to the denigration of the power of African men (Fanon 1967). The religious sphere constitutes a place in the margins of this daily depreciation where the power of men is reaffirmed and celebrated. Pentecostal affiliation seems to temper the difficulties of migrant men by formally claiming the precedence of men over women and by recognizing in the same discursive movement the quality and importance of the "female workers of the Lord."

These spaces also constitute places of debate, contest, negotiation around the morality or lack thereof of local practices, and sites of evaluation of recent sexual evolutions. In a very general way, the western laxness in terms of customs and sexual practices is the object of deep criticisms during religious meetings. The image or, in certain cases, the caricature of the sexual practices of others serves then to consolidate the sexual orthodoxy of the members of the assembly. The religious condemnation of homosexuality and the legislative advances with regard to these sexual minorities is recurring (in particular, same-sex marriage which has been permitted in Belgium since 2003). Pastors warn their flock in the following terms: these illegitimate practices bring only the destruction of the individual. The transgression of the moral standards has a price. They quote then the first letter to the Corinthians: "Do not you 
know that the inequitable will not inherit from the Kingdom of God? Do not get lost. Distracted, admirers of statuettes, adulteries, liabilities, sodomites, thieves, grasping, drunkards, insulters, birds of prey will not inherit from God's reign" (Corinthians I, 6: 9-10).

Certain ministers qualify homosexual practices as ignominies. They use metaphors structured around the nature/culture dichotomy in order to relegate these practices to the animal kingdom, to savagery, to bestiality.

For a pastor native of DRC, homosexual practice is comparable to the act of eating one's own excrement. One pastor admitted to having already dealt with homosexuals in his church, where he proceeded to organize sessions of special prayers to free them from this vice. He concluded by narrating a story with a "happy ending" as he said, in which one of these believers, by means of prayer, was stopped from being homosexual. This way, the masculinity valued in these spaces joins the hegemonic masculinity in the sense of privileging the virility of men to the detriment of homosexual identities, perceived as deviant.

\section{PRODUCING MEN OF HEART}

If male dominance is confirmed by this religious reading, other processes in the margins of this valorisation come to moderate the strictly patriarchal aspect of gendered relations. Indeed, the Pentecostal reworking of masculinity also implies a subversion of the hegemonic masculinity. Male domination is thus established, yet this is limited and redirected towards a model of masculinity that we could qualify as alternative. Indeed, Pentecostal affiliation proposes to break with certain dominant cultural values.

Two processes contribute to new directions for religious masculinity: on the one hand, men are "domesticated," to use the expression of Elisabeth Brusco (1995), and on the other hand, we observe the "feminization of masculinity" in these spaces (Mansilla Agüero 2007).

\section{The male domestication}

As I expand upon below, gender is a game played by both male and female individuals; masculinity and femininity as structural patterns are "worked on" by the same religious principles. The first process being summed up is the one of domesticity. Indeed, this concept is not exclusively meant as a study of women's issues! If the domestic sphere is, above all, the "kingdom" of women, and if this sphere is extended to the religious space by taking care of children and housekeeping, men are also "domesticated" in a way. They have to be ideal husbands, caring and loving fathers: faithful, loyal and responsible like the model of Jesus.

Their concerns are refocused within the household, the domestic unit. In this sphere, the man has a position of head but his aspirations have changed to 
correspond closer to those of his wife (Brusco 1995: 148). If we re-examine the speech of "Maman" Jessica above, we can see that after having exhorted her "sisters in Christ" to submit to their husbands, Jessica orders the men, those whom she describes as the "leaders," to take their "responsibilities." "We do not want omelettes" she ends with a touch of humour. If the incitement of submission for the women is very clear, it does not go without the counterpoint for the men of the assembly, whom the women expressly ask to shoulder their responsibilities.

It is as if the compensation for the repetitive call for female submission is that women expect a certain type of masculinity. To a certain extent, women say: "OK, we will submit to you men but you will have to live up to our requirements." As Melanie Heath puts it: "by helping 'men to be men,' the wives promote a hegemonic masculinity that allows men to be involved husbands and fathers while maintaining their privilege as men" (2003: 436). This gender configuration is confirmed by other studies about evangelicals that have shown how women restore the precedence of men to sustain the harmony of the domestic unit (Gallagher and Smith 1999; Stacey and Gerard 1990).

In this context, women do not aim to directly oppose the current patriarchy; they rather hope that God will moderate the hearts of the men of the assembly (Mate 2002: 566). Their Pentecostal affiliation allows them to formulate, in a specific biblical language, certain requirements about the way to be men. The contents of this masculinity are thus redefined according to a new structure of power. As explained by one of the Zimbabwean Pentecostal interlocutors of Rekopantswe Mate, the male authority rests on the bible: "male headship is ordained in the Scriptures and [...] it is not about tyranny because a man who follows the Bible knows better than to be dictatorial, abusive or otherwise 'unfair' to his wife and children" (2002: 554).

What this means is that the man has to show an enlightened usage of his power based on the consultation with those for whom he is responsible. Submission, power and responsibility are invested with particular meanings in these spaces: they constitute the trio of normative orders in the heart of the relations between Pentecostal men and women. It is the reason for which Bernice Martin (2001) asserts that these movements, qualified as "regressive," "patriarchal," or as "fundamentalists," have nevertheless contributed to the emancipation of millions of women in or from "the South." The author adds that the signs of emancipation are difficult to perceive for the western observers influenced by the Age of Enlightenments for whom Pentecostalism is above all marked by a lack of intellectual sophistication (2001: 57).

This domestication also extends to sexual issues. Pentecostal men and women want to distance themselves from the rest of the world by a sexual moral order. Women have to be calm and thoughtful of their husbands' desires, and the assembly expects them to be beyond reproach as far as being a vehicle 
of temptation. Sensuality in Pentecostal rhetoric is understood as a tool of Satan, a trap inscribed in women's bodies, often without her knowing it, set to ensnare men. The result of this association is that great attention is paid to the sexuality of young girls. As mentioned elsewhere (Maskens 2011 ), young girls constitute the purity "potential" of a congregation. Pastors are concerned with female sexuality in the everyday life of their church. Young women are the real target of concerned sermons. Young men are generally spared such sermons because of the shared common assumption about their sexuality, understood as indomitable, uncontrollable. For young men, masculinity is an aggressive one, a "virile" masculinity. So, without entering into more detail here, this leads us to this point: if we can notice the coexistence of a plurality of masculinities, reworked by the same religious process and differently inhabited by the sexes, there is also a kind of temporality affecting the authorized definition of masculinities. There are different masculinities embedded in different stages of the life cycle.

\section{The feminization of masculinity}

The second process at the heart of the Pentecostal reworking of the masculinity, namely the "feminization of masculinity," also breaks with the dominant cultural values. Indeed, as Almeida admirably showed in his study of a village in Southern Europe, the hegemonic masculinity, as an ideal cultural model, exercises control over all the men by incorporating a specific sociability to the everyday life and through discourses which exclude the emotional dimension of existence by its identification as feminine (Almeida 1995: 17). The men build themselves then in opposition to this feminine counterpart. The expression of feelings, to cry for example, is reserved for the women only. The religious spaces take the opposite view of this gender standard and the emotion and its manifestations are not only the privilege of women.

The domestication of male followers goes hand in hand with the shaping of their personality. Men are encouraged to "be connected" with their nuclear and spiritual circle - they must try every day to be connected with God. Men have to feed the family literally as well as morally by bringing peace and serenity to the household. Gentleness and affection in these spaces become masculine attributes. Demonstrating this attribute, Mario, a Guatemalan follower for more than 40 years, living in Belgium for about 12 years and attending the biggest Congolese Church in Brussels, said, after a long prayer during which tears were running down his face: "Society says you cannot cry, you cannot be sensitive otherwise you are considered gay. But for God, men can cry, be sensitive, love [...]. You're also told that you have to fuck to be a man otherwise we say you're homosexual, but it is wrong too."

If, in the majority of social worlds, a man crying or showing his fragility doesn't fit with what is generally expected of the "stronger sex" and such 
men run the risk of seeing their masculinity disqualified, in religious spaces men can "be connected" safely. This kind of alternative masculinity rejects some patterns of a "virile" masculinity, those that don't fit with their role as good fathers, for example, but stays in touch with this model on questions such as authority, heterosexuality, and the evidence of "natural" dissimilarities between men and women.

To illustrate this alternative masculinity, the comments of Octave are relevant. He is a young Belgo-Congolese man under 30, who described himself as "born in the church" and with whom I had an enlivened conversation at his home about what it is to be a Christian man in the twenty-first century:

"Well, we have to put things in their context. It's true that in the Bible, it's like that: a woman is submissive to her husband. But, if you're a gallant man and you know that there is a woman God has given to you, you have to do everything possible to take care of her and she too has to do everything to treat you well. And if she has to prepare meals and so on to treat you well, she will do it but only if she has enough time. Because you should not be fooled... we are in Europe in 2006! I have some female friends that have little kids: it's killing them! If you have four, you have a head like that. You have to have a heart: if men have to take a vacuum cleaner to help cleaning, they should do it! You see, it's you and your wife that know and it will stay in the family circle. My father, he has vacuumed before because my mother's back was hurting or whatever... Or to do the washing-up for example, my father has also done the washing-up."

During this discussion, Octave mentions gallantry, common sense and compassion, all qualities that men of the Lord have to demonstrate towards their spouses. A Christian man could develop his sensitivity - without running the risk of emasculation because his status as head of the family household is guaranteed - and as such, they are able to adopt behaviours suitable for the context ("we are in Europe," "we are in 2006") and call for compassion. Similar discourses emerge from the analyses of Jacinthe Mazzocchetti in her study on the students of Ouagadougou, in Burkina Faso, the country of origin of certain pastors and other Pentecostal believers in Brussels. The anthropologist describes two believers in the Assemblies of God, a young couple called Michel and Christine who also testify to the tendency of a more egalitarian reformulation of the strict distribution of housework. Indeed, the couple agrees to assume a distribution of the tasks less centred on the work of women. Michel speaks about the fact that he is not hampered by the outsiders' opinions because he is committed to showing a good attitude. Christine denounces the negative view of wider society which places a man in flagrante delicto of domestic cleaning, and Mazzocchetti concludes: "if the relationships of domination 
are reaffirmed within these Churches, relations between men and women in the Protestant couples distance themselves from present observed norms" (2009: 215).

In our example above, Octave doesn't question the model of strict separation of tasks: it's clear that women take charge of domestic and child-care tasks (they are the ones that "naturally" prepare meals, vacuum and do the washing-up), but men have to relieve them if they are suffering. His revelation concerning the cleaning actions of his father reinforces the exceptional nature of such acts and consolidates the idea of a strict separation of tasks. This ambiguity is thus at the heart of the Pentecostal redefinition of masculinity. There is a duality of detachment and proximity. Male followers try to distance themselves from the culturally dominant form of masculinity as formulated by society but, at the same time, they reinforce and consolidate some patterns of it by using its religious legitimacy.

\section{FAILED DOMESTICATION}

If this article deals first and foremost with the discursive production of normativity and consequently authority, it is not to be said that the concrete and daily transformation of masculinity is beyond its scope. Indeed, the young men who do not show a change of behaviour expected in the religious space can be the objects of closer control by the pastoral authorities. The figure of the "seducer" does not enter within the framework of Pentecostal masculinity and is thus deeply "disputed." Anything resembling sexual predation is firmly repressed in these spaces. In certain cases, it happens that the religious authorities of the church intervene directly during the hook-up scene of certain believers. This is particularly the case when a male believer's attempts to approach girls or women are made in a visible way within the cult, in front of other members of the assembly. This was the case with a young faithful Peruvian, who systematically sat next to me during the cults and suggested that we participate together in diverse activities. The pastor of this Hispanic Church came regularly to interrupt him and to present me to the other persons of the church, especially the women, and by doing so showed me the procedure. During a conversation, the Peruvian pastor shared his disapproval regarding the behaviour of the same believer towards me, referring to the latter as a "philanderer." Obviously irritated, the pastor explained to me: "Certain believers look at all the new persons who arrive at the church and try to seduce them. They 'declare' themselves to all new believers, then the girls do not give them importance. They are not mature, nor responsible, they are not persevering, they are not sincere. We have to fight against it."

In Latin American spaces, the figure of the "macho man" - part of the hegemonic masculinity par excellence of this continent - is more thematised 
and fought for than in the church composed for the greater part of native of Sub-Saharan Africans. The Mexican origin and the history of the term explain this ascendancy. In the literature on the South-American Pentecostalism, there are many authors who bring to light how much the religious affiliation breaks with this crucial character in the history of masculinities (see e.g. Hallum 2003; Austin-Broos 1997; Chesnut 1997; Brusco 1995).

It is also worth noting that male interlocutors, according to their own perception of my position in the church (as a member for some, as a non-member for others) constructed their desire differently. ${ }^{7}$ For Ernest, a male in his thirties, recently arrived from Niger and frequenting La Parole Vivante, the fact that I was part of the church was something really valuable. So, additionally to the fact that I was Belgian, young, and unmarried, he perceived me as a Christian. When I explained that I already had a boyfriend, he responded: "It's a pity because I have feelings for you and furthermore, somebody like you who live in prayers..." In contrast, in my encounter with the young Belgo-Congolese Octave, in his late twenties, it was precisely my position of externality to the church that made me desirable. Two weeks after having done a formal and recorded interview, he called me so that I could give him the audio tape back because he was uneasy with such comments and wanted to destroy the evidence. I accepted and he came to my home to pick me up in his car and took me to a park in the neighbourhood. He stopped the car and grabbed the beers hidden beneath the back seat. Then he began to talk about the difficulties in a relationship with a girl from the church. They were living together but the parents of his girlfriend were really upset with such relations outside marriage. He proposed then to have sex in an almost unveiled way and justified himself in this way: "because you know, a young Christian girl cannot anymore, it's a chore, while you..." He associated non-Christian women as readily available women sexually speaking.

Such situations highlight the tacit dimension of masculinity, far from the discursive performance of cults, public testimonies or formal presentation of the Pentecostal self to non-converted people. Sometimes I could witness how those churches' messages were put into practice. After a cult where the pastor had talked again about the fact that women have to be submitted to men, giving concrete examples, Paul, the Rwandese guitarist of the assembly, asked to Simone, a single Congolese in her thirties, to clean up the table in the hall and he added "you are a women, you have to submit!" Simone accomplished this task without flinching. In this scene of power, we can see how the practical application of being a man in the church depends strongly on the context and could follow multiple lines and intensities of power.

7 For a discussion of the erotic subjectivity of the anthropologist, see Kulick (1995). 


\section{CONCLUSION}

The Pentecostal reworking of masculinity takes place as a rupture or transformation from the "old man" to the "new man" through a non-linear process of purification. The man is domesticated: his concerns are refocused around the needs and well-being of the household. He is also feminized in a way. These normative processes are articulated alongside notions of change, but it should not allow us to forget the weight of individual appropriation in these phenomena. The process of transformation will not be imprinted in the same way on every believer who conducts a sorting of the multiplicity of discourses on masculinities according to his or her biographic echoes. The religious proposition constitutes one possibility among other available stocks.

In a dialectic which associates distance and closeness, men of the assembly appear as "new" by distancing themselves from the dominant cultural hegemonic form of masculinity, so answering the imperative of distinction of the religious gathering, and yet, by dressing in the "new clothes of the male domination" (De Singly 1993), they strengthen certain dominant tendencies - the precedence of the male component in the social organization - by leaning on the legitimacy of the religious register.

The ambiguity is thus at the heart of the Pentecostal redefining of masculinity. The men of the assembly, particularly those in the age bracket of 35-50 years, seem to feel their privileges threatened, and this feeling exceeds the borders of the religious or migratory spaces because it is shared by numerous non-migrant western and non-western men (Welzer-Lang and Filiod 1992). However, the threats pressing on the privilege of men seem to become intensified in the migration towards Europe. Migrant men experience greater challenges to their capacity as providers, and are at the same time confronted with other gender ideologies. This potential destabilization of their status finds an answer in the religious affiliation to Pentecostalism(s). This religious ideology, which redefines the male role by establishing a "biblical" male precedence is thus one way, among others, to understand male resistance in the contemporary transformations affecting gendered norms. 


\section{REFERENCES}

ALMEIDA, Miguel Vale de, 1995, Senhores de Si: Uma Interpretação Antropológica da Masculinidade. Lisbon, Fim de Século.

AUSTIN-BroOS, Diane J., 1997, Jamaica Genesis: Religion and the Politics of Moral Orders. Chicago, The University of Chicago Press.

BANCEL, Nicolas, et al., 2010, "Introduction: de la fracture coloniale aux ruptures postcoloniales”, in N. Bancel et al. (eds.), Ruptures postcoloniales: Les nouveaux visages de la société française. Paris, La Découverte.

BOZZOLI, Belinda, 1983, Town and Countryside in the Transvaal. Johannesburg, Ravan Press.

BRACKE, Sarah, 2008, "Conjugating the modern/religious, conceptualizing female religious agency: contours of a 'post-secular' conjuncture”, Theory, Culture \& Society, 25 (6): 51-67.

BROUWER, Steve, Paul GIFFORD, and Susan ROSE, 1996, Exporting the American Gospel: Global Christian Fundamentalism. New York, Routledge.

BRUSCO, Elisabeth, 1995, The Reformation of Machismo: Evangelical Conversion and Gender in Colombia. Austin, TX, University of Texas Press.

BUTLER, Judith, 1993, Bodies that Matter: On the Discursive Production of Sex. London, Routledge.

CAMPICHE, Roland, 1996, "Religion, statut social et identité féminine", Archives des Sciences Sociales des Religions, 95 (1): 69-94.

CHESNUT, Andrew, 1997, Born Again in Brazil: The Pentecostal Boom and the Pathogens of Poverty. New Brunswick, Rutgers University Press.

CONNELL, Bob, 2002, "Hegemonic masculinity", in S. Jackson and S. Scott (eds.), Gender: A Sociological Reader. London, Routledge, 60-62.

CUCCHIARI, Salvatore, 1990, "Between shame and sanctification: patriarchy and its transformation in Sicilian Pentecostalism”, American Ethnologist, 17 (4): 687-707.

DE SINGLY, François, 1993, "Les habits neufs de la domination masculine”, Esprit, 196: 54-64.

DELANEY, Carol, 1998, Abraham on Trial: The Social Legacy of Biblical Myth. Princeton, Princeton University Press.

EIESLAND, Nancy L., 1997, "A strange road home: adult female converts to classical Pentecostalism", in J. Brink and J. Mencher (eds.), Mixed Blessings: Gender and Religious Fundamentalism Cross Culturally. New York, Routledge, 91-116.

FANCELLO, Sandra, 2005, "Pouvoirs et protections des femmes dans les Eglises pentecôtistes africaines", Revista de Estudos da Religião, 3: 78- 98.

FANON, Franz, 1967, Black Skin, White Masks. New York, Grove.

GALlAGHER, Sally K., and Christian SMITH, 1999, "Symbolic traditionalism and pragmatic egalitarianism: contemporary evangelicals, families and gender", Gender and Society, 13 (2): $211-233$.

HALLUM, Anne Motley, 2003, “Taking stock and building bridges: Feminism, women's movements, and Pentecostalism in Latin America", Latin American Research Review, 38 (1): 169-186.

HEATH, Melanie, 2003, "Soft-boiled masculinity: renegotiating gender and racial ideologies in the Promise Keepers movement", Gender and Society, 17 (3): 423-444. 
HIRSCH, Jennifer, 2007, “'Love makes a family’: globalization, companionate marriage, and the modernization of gender inequality", in M. Padilla et al. (eds.), Love and Globalization: Transformation of Intimacy in the Contemporary World. Nashville, Vanderbilt University Press.

HODGSON, Dorothy L., 2001, "Of modernity/modernities, gender, and ethnography", in D. L. Hodgson, Gendered Modernities: Ethnographic Perspectives. New York, Palgrave, 1-22. HOLLYWOOD, Amy, 2004, "Gender, agency, and the divine in religious historiography", Journal of Religion, 84 (4): 514-528.

ILlOUZ, Eva, 2012, Pourquoi l'amour fait mal? L'expérience amoureuse dans la modernité. Paris, Editions du Seuil.

JEWSIEWICKI, Bogumil, 2004, “Kinshasa: (auto)représentation d'une société 'moderne' en (dé)construction. De la modernisation coloniale à la globalisation”, Cahiers Africains, 65-67: 161-186.

JOLY, Vincent, 2011 , “'Races guerrières' et masculinités en contexte colonial: approche historiographique”, CLIO: Histoires, Femmes et Sociétés, 33: 139-156.

KIBRIA, Nazli, 1993, Family Tightrope: The Changing Life of Vietnamese Americans. Princeton, Princeton University Press.

KRONDORFER, Björn, 2009, "Introduction”, in B. Krondorfer (ed.), Men and Masculinities in Christianity and Judaism: A Critical Reader. London, SCM Press, xi-xxi.

KULICK, Don, 1995, "Introduction: the sexual life of anthropologists. Erotic subjectivity and ethnographic work", in D. Kulick and M. Willson (eds.), Taboo: Sex, Identity and Erotic Subjectivity in Anthropological Fieldwork. London, Routledge, 1-28.

KUYU MWISSA, Camille, 2008, Droit et société au miroir de la chanson populaire: anthropologie juridique des relations entre les sexes à Kinshasa. Louvain-La-Neuve, Académia-Bruylant.

LANGE, Barbara Rose, 1996, "Gender politics and musical performers in the Isten Gyulekezet: a fieldwork account”, Journal of American Floklore, 109: 60-76.

LAWLESS, Elaine J., 2003, "Transforming the master narrative: how women shift the religious subject”, Frontiers Boulter, 24 (1): 61-75.

MACHILLOT, Didier, 2011 , “'Machos' et 'machistes': (brève) histoire de stéréotypes mexicains", Amerika , 4, available at < http://amerika.revues.org/2149> (last access May 2015).

MACKENZIE, John, 1989, Imperialism and Popular Culture. Manchester, Manchester University Press.

MAHMOOD, Saba, 2005, Politics of Piety: The Islamic Revival and the Feminist Social Theory. Cambrigde, Polity Press.

MANSILlA AGÜERO, Miguel Angel, 2007, "La construcción de la masculinidad en el pentecostalismo chileno", Polis, 16, available at < http://polis.revues.org/4722 > (last access May 2015).

MARTIN, Bernice, 2001, "The pentecostal gender paradox: a cautionary tale for the sociology of religion”, in Richard K. Fenn (ed.), The Blackwell Companion to Sociology of Religion. Oxford, Blackwell, 52-66.

MASKENS, Maïté, 2011 , "Le traitement de la virginité chez les migrants pentecôtistes à Bruxelles”, L'Espace Politique, 13, available at < http://espacepolitique.revues.org/1847> (last access May 2015).

MASKENS, Maïté, 2012, "Mobility among Pentecostal pastors and migratory 'miracles', Canadian Journal of African Studies/La revue canadienne des études africaines, 46 (3): 397-409 . 
MASKENS, Maïté, 2013, Cheminer avec Dieu: pentecôtismes et migrations à Bruxelles. Brussels, Editions de l'Université de Bruxelles.

MATE, Rekopantswe, 2002, "Wombs as God's laboratories: Pentecostal discourses of femininity in Zimbabwe", Africa: Journal of the International African Institute, 72 (4): 549-568.

MAZZOCCHETTI, Jacinthe, 2009, Etre étudiant à Ouagadougou: itinérances, imaginaire et précarité. Paris, Karthala.

McNAY, Lois, 2000, Gender and Agency: Reconfiguring the Subject in Feminist and Social Theory. Cambridge, Polity Press.

MEIERS, Bénédicte, 2013, Le Dieu de Maman Olangi. Louvain-la-Neuve, Harmattan-Academia.

MIESCHER, Stephan F., and Lisa A. LINDSAY, 2003, "Introduction: men and masculinities in modern African history", in S. F. Miescher and L.A. Lindsay (eds.), Men and Masculinities in Modern Africa. Portsmouth, Heinemann, 1-29.

PESSAR, Patricia, 1995, "On the homefront and in the workplace: integrating immigrant women into feminist discourse", Anthropological Quartely, 68 (1): 37-47.

SACKEY, Brigid, 2006, New Directions in Gender and Religion: The Changing Status of Women in African Independent Churches. Lanham, Lexington Books.

SAYAD, Abdelmayek, 1999, La double absence: Des illusions de l'émigré aux souffrances de l'immigré. Paris, Editions du Seuil.

SCOTT, Joan W., 1988, "Gender: a useful category of historical analysis", in J.W. Scott, Gender and the Politics of History. New York, Columbia University Press, 28-50.

SINHA, Mrinalini, 1995, Colonial Masculinity: The "Manly Englishman" and the "Effeminate Bengali" in the Late Nineteenth Century. Manchester, Manchester University Press.

STACEY, Judith, and S.E. GERARD, 1990, “We are not doormats': the influence of feminism on contemporary evangelicals in the United States", in F. Ginsburg and A. L. Tsing (eds.), Uncertain Terms: Negotiating Gender in American Culture. Boston, Beacon Press, 98-117.

SUH, Sharon, 2003, “'To be Buddhist is to be Korean': the rhetorical use of authenticity and the homeland in the construction of post-immigration identities”, in J. N. Iwamura and P. Spickard (eds.), Revealing the Sacred in Asian and Pacific America. New York, Routledge, 177-192.

VAN KLINKEN, Adriaan, 2011 , "Male headship as male agency: an alternative understanding of a 'patriarchal' African Pentecostal discourse on masculinity", Religion and Gender, l (1): 104-124.

VOYÉ, Liliane, 1996, "Femmes et Eglise catholique: une histoire de contradictions et d'ambiguïtés”, Archives des Sciences Sociales des Religions, 95 (1): 29-45.

WELZER-LANG, Daniel, and Jean-Paul FILIOD (eds.), 1992, Des Hommes et du Masculin, Aix en Provence, Presses Universitaires de Lyon.

WILLAIME, Jean-Paul, 1996, "L'accès des femmes au pastorat et la sécularisation du rôle de clerc dans le protestantisme”, Archives des Sciences Sociales des Religions, 95: 29-45.

WILLAIME, Jean-Paul, 1999, "Le pentecôtisme: contours et paradoxes d'un protestantisme émotionnel”, Archives des Sciences Sociales des Religions, 105: 5-28. 